\title{
THE IMPLEMENTATION OF QUANTUM LEARNING MODEL USING SOCIAL-SPIRITUAL VALUE THROUGH LESSON STUDY TO IMPROVE SOCIAL-SPIRITUAL ATTITUDES AND LEARNING RESULTS OF SCIENCE II BASIC CONCEPT
}

\author{
I Gede Astawan ${ }^{1}$, Dewa Nyoman Sudana ${ }^{2}$ \\ ${ }^{1}$ Ganesha University Of Education, Singaraja, Indonesia \\ ${ }^{2}$ Ganesha University Of Education, Singaraja, Indonesia
}

\section{A R T I C L EI N F O}

Article history:

Received 19 April 2016

Received in revised form 6 October 2016

Accepted 12 October 2016

Available online 20 October 2016

Keywords:

quantum learning, socialspiritual attitudes, lesson study

\begin{abstract}
A B S T R A C T
The research objectives were (1) to improve the social-spiritual attitudes of students through the application of quantum learning models containing socialspiritual values through lesson study. (2) To improve the learning outcomes of students' basic science II science concepts through the application of quantum learning models containing social-spiritual values through lesson study. The method used to achieve the above objectives is the method of action research. The data collected were social-spiritual attitudes with questionnaires and the learning outcomes the basic concepts of science II with tests. The data analysis technique used is descriptive statistics. The research findings are (1) the application of quantum learning models containing social-spiritual values through lesson study can improve students' social-spiritual attitudes. This can be seen increasing from cycle I to cycle II at $13.28 \%$. (2) Application of quantum learning models containing social-spiritual values through lesson study can improve learning outcomes of students' basic science II concepts. This can be seen increasing from cycle I to cycle II at $12.25 \%$. Based on the findings of this study, it is recommended that teachers / lecturers use the quantum learning model with the value of social-spiritual attitudes as an alternative to innovative learning models in order to improve the social-spiritual attitudes and learning outcomes of students. Further researchers are advised to examine in a relatively longer time to see the effectiveness of the quantum learning model with the value of social-spiritual attitudes in improving the social-spiritual attitudes and learning outcomes of students.
\end{abstract}

\section{Introduction}

The implementation of education as mandated in Law Number 20 of 2003 concerning the National Education System is expected to realize the process of developing the personal qualities of students as the future generation of the nation, which is believed to be a determinant factor for the growth of the Indonesian nation and state throughout the ages. The personal qualities referred to in the law, according to the Ministry of Education and Culture (2013a) are personal reflecting: (1) quality human beings who are capable and proactive in responding to the challenges of an ever-changing era; and (2) educated people who believe and fear God Almighty, have noble character, are healthy, knowledgeable, capable, creative, independent; and (3) democratic and responsible citizens. Based on this description, it appears that the people who want to be produced by the Indonesian people are those who are intellectually intelligent and emotionally, socially-spiritually intelligent.

Various efforts have been made by the government to realize intelligent people, namely (1) improvement of curriculum, (2) development of science learning models, (3) development of science learning media, (4) upgrading for educators, (5) provision of facilities which supports science learning, (6) training and seminars, and (7) and others. However, it should be recognized that these efforts have not 
shown encouraging results. The United Nations Development Program (UNDP) reports Indonesia's Human Development Index (HDI) is ranked 109th out of 179 countries (UNDP, 2009). In 2005, it was revealed that the quality of education in Indonesia was ranked 10th out of 14 developing countries in the Asia-Pacific region. This rating was reported from a global monitoring report issued by the UN agency, UNESCO (Muslich, 2009).

In connection with the efforts that have been made, aspects of the curriculum become one of the important components. Since 2013, the 2013 curriculum has begun to be implemented. The 2013 curriculum, which is now still being implemented, is being socialized and tested on a limited basis, bringing a new spirit towards better change. Although in the end, the government issued a new policy which essentially delayed the implementation of the 2013 curriculum. One important aspect that needs to be noted in the 2013 curriculum is the addition of core competencies at every level of education / learning. Core competency is related to spiritual attitudes and social attitudes.

Development of aspects such as cooperation, respect for opinions, recognizing oneself and others, and the like need to be grown in learning. This is in line with the spirit of learning in college, namely studying in college is not only required to have technical skills, but also has the power and frame of mind and mental attitude, personality, wisdom, and broad insight. All that will be achieved by preparing adequate facilities / infrastructure and infrastructure and must be utilized.

Science learning so far has not contained much content of social attitudes and spiritual attitudes. Presentation is more centred on content (material) only. Whereas the meaning of the content is mainly social value and the spiritual value in it has not been explored. This causes the social attitudes and spiritual attitudes of students to grow and develop less. Based on interviews with students, stated that there were no lecturers in the science course who related the material to the social values and spiritual values contained in the content of material.

In fact, according to students the planting of social values and spiritual values is very important. Through planting social and spiritual values will be able to touch the hearts of students so that they become better individuals. Thus, there is a balance of student intelligence between academic intelligence and socialspiritual intelligence. In this regard, this study applies a quantum learning model containing socialspiritual values through lesson study to improve social-spiritual attitudes and learning outcomes of the basic concepts of science II.

Quantum teaching always adheres to the principle of "bringing their world into our world and delivering our world to their world" (DePorter, et al., 2001: 9). This states that as the first step that educators need to think about is the importance of entering the world of students. Because the essence of educators to obtain teaching rights should build outentic bridges to enter the world of students (DePorter, et al., 2001: 10; Wenger, 2003). To find out the world of students, educators must first explore what they already know, and what they want to know, so that learning goes according to what the students want, not what the educator wants to achieve. The principle of quantum teaching, gives the meaning that the learning carried out must pay attention to the students' initial knowledge. Educators, tasked with facilitating students to change their initial knowledge labeled misconceptions into scientific concepts. To be able to facilitate it, learning should be centered on students (student centered). So, teaching must always be associated with learning which is full-contact action that always involves all aspects of the human personality - thoughts, feelings, body language, knowledge, initial attitudes, and perceptions of the future.

Entering the world of students is an effort to obtain permission to lead, guide, and facilitate their journey in building awareness and knowledge. These efforts can be carried out, among others, by directly linking concepts that will be studied with daily events or experiences, for example from home, social, athletic, music, art, recreation, or directly related to the academic knowledge they already have .

In implementing the quantum learning model the stages known as the acronym are used. First, the growth stage is to grow students' interest in learning by answering the questions What are the Benefits of My Teachers (AMBAK), and take advantage of student life. Strategies that can be chosen, namely by linking content (material) to the context (real life learners) and asking a number of questions to students in relation to the concepts to be discussed, this is intended to determine the initial knowledge possessed by students and students. This initial knowledge can be used as a platform by educators to carry out the learning process

Second, the natural stage is to create or provide opportunities for students to gain understandable experiences. The process of how students respond to questions / problems will be able to know whether the knowledge of students is correct or almost correct. Students are given the opportunity to experience themselves and be directly involved in learning. This will improve students' skills in solving problems.

Third, the naming stage is to provide key words, instructions, and strategies, then discussed in the context of what was observed in the previous stages. This naming process will satisfy the brain's desire to 
know (Rose and Nichall, 1997; De Porter, et al., 2001). The learning process that is carried out should be able to stimulate the curiosity of students about the concepts learned. After growing curiosity of students, educators facilitate students to understand (give meaning) what they do.

Fourth, demonstration is to provide opportunities for students to demonstrate their ability to construct knowledge / concepts. The strategy used is to ask students to explain again with their own words about the material being studied, provide opportunities for students to perform performance, present their work, and discuss it. Educators as creative facilitators and mediators, so that discussions can work well.

Fifth, the repeat phase is to convince students that they really know what they are learning. The strategy by means of students is given the opportunity to review the extent to which they have understood the concepts being taught. In addition, it can also be done by providing opportunities to work on individual practice questions to improve students' understanding of the material being studied. This repetition is intended to convince students that they do know what is known. Thus, students will be more stable towards what was previously understood. This makes students fun, fun, and can increase understanding.

Sixth, the stage of celebrating is giving recognition of the completion, participation, and acquisition of skills and knowledge by students. As a form of appreciation for the efforts that have been made by students, it should be celebrated. Strategies that can be chosen by giving praise, pleasant perceptions to students, provide reinforcement to students who experience progress in learning, and motivate students to continue the spirit of learning. This is in accordance with the principle "if it is worth studying, it is worth celebrating". Through this stage of celebration, students can develop self-confidence. Thus, students become optimistic and motivated to learn better.

Value is a fundamental thing that is noble and universal in someone. Broadly speaking, Linda (in Elmubarok, 2009) values are divided into two groups, namely values of being and values of giving. Conscience values include: honesty, courage, peace of mind, self-reliability, and others. While giving values include: faithful, trustworthy, respect, love, and others. Furthermore, Linda (1995) defines value education as planting and developing values in a person. In connection with these values, according to Licona (in Sadia, et al., 2013) states that there are a number of values that need to be taught through character education, namely (1) honesty, (2) openness, (3) tolerance, (4) health attention, (5) selfdiscipline, (6) sincere help, (7) compassion, (8) cooperation, (9) determination, and (10) democratic values.

Whereas in the 2013 curriculum, the values to be invested were divided into two groups, which were reflected in core competencies (Ministry of Education and Culture 2013b). These core competencies are spiritual attitudes and social attitudes. Spiritual attitudes include: Accepting, appreciating, and carrying out the teachings of the religion they adhere to, and social attitudes include: Having honest, disciplined, responsible, polite, caring, confident, and loving homeland in interacting with family, friends, neighbors and teacher.

\section{Methods}

This research was designed using Classroom Action Research (CAR). The research subjects were 34 people consisting of 16 men and 18 women. The object of this class action research, namely the quantum learning model which contains social-spiritual values, sets lesson study, social-spiritual attitudes and learning outcomes of the basic concepts of science II. PTK is carried out following the pattern of Kemmis and Taggart (1988), which is spiral in shape from one cycle to the next. Each cycle consists of four stages, namely: (1) planning, (2) action, (3) observation / evaluation, and (4) reflection. Each of these stages is combined with the lesson study pattern, namely plan (plan), do (implementation), and see (reflection). The data collected in this study are social-spiritual attitudes and learning outcomes of the basic science concepts of 2 students. Data on social-spiritual attitudes were collected using questionnaires. The questionnaire uses a Likert scale. Data on learning outcomes of basic science concepts 2 students are collected using tests. Data on learning outcomes and social-spiritual attitudes were analyzed descriptively based on average score (MX), standard deviation (SD), and percentage increase (P). The success criteria for social-spiritual attitudes in this class action research are determined if the average score of students' social-spiritual attitudes is in the high minimum category and there is a percentage increase in socialspiritual attitudes. The criteria for success in learning outcomes in this study are set at a minimum the average score reaches a high category, learning completeness is at least $85 \%$, and there is a percentage increase in learning outcomes. 


\section{Findings and Discussion}

The results of data analysis in the first cycle showed that the average score of students' socialspiritual attitudes was 29.90 with a standard deviation of 4.29. Based on the predetermined classification, students' social-spiritual attitudes are in a sufficient category. The results of data analysis in the second cycle showed that the average score of students' social-spiritual attitudes was 34.00 with a standard deviation of 3.87. Based on the predetermined classification, students' social-spiritual attitudes are in the high category. The score distribution of students' social-spiritual attitudes in the first cycle and second cycle are presented in Table 1.

Table 1. Distribution of Student Social-Spiritual Attitude Scores in Cycle I

\begin{tabular}{llllcll}
\hline No & $\begin{array}{l}\text { Interval } \\
\text { class }\end{array}$ & Categories & $\begin{array}{l}\text { Cycle I } \\
\text { Frequency }\end{array}$ & Percentage & $\begin{array}{l}\text { Cycle II } \\
\text { Frequency }\end{array}$ & Percentage \\
\cline { 2 - 7 } 1 & $60-75$ & Very high & 0 & $0 \%$ & 5 & $14,7 \%$ \\
2 & $50-59$ & High & 18 & $53 \%$ & 26 & $76,5 \%$ \\
3 & $40-49$ & Average & 16 & $47 \%$ & 3 & $8,8 \%$ \\
4 & $30-39$ & Low & 0 & $0 \%$ & 0 & $0 \%$ \\
5 & $15-29$ & Very low & 0 & $0 \%$ & 0 & $0 \%$ \\
\hline
\end{tabular}

Based on Table 4.1, in the first cycle the distribution of students' social-spiritual attitudes is $0 \%$ in the general category the average social-spiritual attitudes of students of Cycle I are in the sufficient category and have not reached the predetermined success criteria. Criteria for success if the student's social-spiritual attitude is at least in the high category. In the second cycle the distribution of students' social-spiritual attitudes was $14.7 \%$ categorized as very high, $76.5 \%$ categorized as high, $8.8 \%$ categorized as sufficient, $0 \%$ categorized as low and very low. At the end of the implementation of the action in the second cycle in general the average score of students' social-spiritual attitudes is in the high category and has reached the predetermined success criteria. There was a very high attitude increase, 53\% in the high category, $47 \%$ in the sufficient category, $0 \%$ in the low and very low theory. In a mannersocial-spiritual from cycle I to cycle II by $13.28 \%$.

The results of data analysis in the first cycle of the basic science learning outcomes of Science II, obtained an average score of 71.32 with absorption (DS) $71.32 \%$, standard deviation of 7.18 and learning completeness (KB) 79.41\%. The results of data analysis in the second cycle of learning outcomes of the basic concepts of IPA II obtained an average value of 74.05 with absorption (DS) of 74.05\%, standard deviation of 6.84 and learning completeness (KB) of $100 \%$. The distribution of the learning outcomes of the basic concepts of Science II in the first cycle and second cycle are presented in Table 2.

Table 2. Distribution of Value of Learning Outcomes of Basic Concepts of Science II in Cycle I and Cycle II

\begin{tabular}{lllllll}
\hline \multirow{2}{*}{ No } & \multirow{2}{*}{ Score } & \multirow{2}{*}{ Explanation } & \multicolumn{2}{c}{ Cycle I } & \multicolumn{2}{c}{ Cycle II } \\
& & & Frequency & Percentage & Frequency & Percentage \\
\hline 1 & $\bar{\chi} \geq 70$ & Tuntas & 27 & $79,41 \%$ & 34 & $100 \%$ \\
2 & $\bar{\chi}<70$ & Tidak tuntas & 7 & $20,59 \%$ & 0 & $0 \%$ \\
\hline
\end{tabular}

Based on Table 2, in the first cycle the distribution of learning outcomes of the basic concepts of IPA II, which was declared complete $79.41 \%$ and not completed $20.59 \%$. Based on the learning completeness (KB) that was determined this study had not been successful because it had not reached KB at least $85 \%$. in the second cycle the distribution of the value of learning outcomes of the basic concepts of science II, which was declared $100 \%$ complete and not completed $0 \%$. Based on the mastery of learning (KB) that was determined this study was successful.

The results showed that there was an increase in social-spiritual attitudes and learning outcomes (HB) of the basic concepts of Science II. The results of data analysis showed that the average score of students' social-spiritual attitudes in the first cycle was 49.59 with a standard deviation of 4.08 (sufficient qualifications). The average score of students' social-spiritual attitudes after the second cycle is 56.18 with a standard deviation of 3.84 (high qualification). An increase in the average score of students' socialspiritual attitudes from cycle I to cycle II was $13.28 \%$. This increase occurs because it is caused by several factors, namely as follows. First, lecturers give recognition of the efforts carried out by students, student 
participation, and the success of students in participating in learning by providing additional value. This recognition can foster student confidence and positive perceptions of learning. Second, announcing the results of the evaluation at the end of the learning activities makes students better prepare themselves to compete positively in achieving goals to be rewarded and obtain better results in the next learning. Third, students begin to get used to the quantum learning model with the value of social-spiritual attitudes. Through the quantum learning model that has the value of social-spiritual attitudes can organize knowledge systematically, facilitate students to understand the material being studied, and help students more easily present the results of work, discuss, and conclude learning outcomes. Interactive students can be established by giving students the opportunity to carry out performance and discussion. In addition, during discussions there will be an exchange of opinions based on logical and scientific arguments. This helps students to be more motivated in finding relevant sources to be able to solve problems and argue well. The quantum learning process with the value of social-spiritual attitudes increases students' motivation to learn better. This makes the value of students' social-spiritual attitudes grow and develop.

The results of this study also showed that there was an increase in learning outcomes of the basic concepts of Science II. The average score of student learning outcomes after the first cycle is 71.32 , absorptive capacity is $71.32 \%$, standard deviation is 7.18 , learning completeness is $79.41 \%$, and qualifications are not complete. The average score of student learning outcomes at the end of the second cycle is 80.06 , the absorption of students is $80.06 \%$, the standard deviation is 7.04 , classical completeness is $100.0 \%$, and is in complete qualification. An increase in the average value of learning outcomes of the basic concepts of science II from cycle I to cycle II was $12.25 \%$.

Looking at the findings above, it appears that the implementation of learning in the first cycle is not optimal. The lack of optimal learning in the first cycle is caused by several factors. First, students are still adapting to the quantum learning model with the value of social-spiritual attitudes because of the habits of students learning with conventional learning models. Second, students are less prepared to study at home, this is due to the limited learning resources that students have. Third, the lack of effective management of the time set by the lecturer. This is because the lecturer must provide guidance to several students who have not been able to understand the MFI properly so that the implementation of learning is not optimal.

Regarding the factors that have caused the optimal learning in the first cycle, improvements are made as follows in cycle II. 1) Provide more intensive guidance to students in solving problems in groups. 2) More motivating students and linking material to the real world of students. 4) Provide assistance in the form of summaries of material from various sources. 5) Fishing students to express their problems through reflection sheets to be discussed together.

The learning process with a quantum learning model with the value of a social-spiritual attitude, arouses the awareness of students to think, speak and act better. Submission of moral messages from each subject matter studied, in addition to preventing student exhaustion can help reassure them. After the students are comfortable again, material learning is continued again.

1.In line with the exposure and based on the results of the reflection carried out, the successful implementation of the quantum learning model contains the value of social-spiritual attitudes because the learning model has several advantages, including the following. The quantum learning model with the values of social-spiritual attitudes is believed to be able to improve the students' social-spiritual attitudes. Through the application of the learning model, students are open minded about good and bad attitudes and behaviors.

2.Lecturers can place their role as inspirators in classroom learning more optimally.

3.Lecturers can place their role as motivators in classroom learning more optimally.

4.Through the implementation of the quantum learning model, the value of the social-spiritual attitude provides an opportunity for lecturers to objectively assess students through observation. Through the assessment rubric, the lecturer can avoid the element of subjectivity in the assessment, but objectively assess students.

5.Through the implementation of the quantum learning model that has the value of social-spiritual attitudes can teach students to be more active and able to reflect learning activities, so that students' minds are fully in the learning process that takes place.

6.Through the excavation of meaning in each lesson helps students realize the values that have been followed so far.

7.Through the implementation of the quantum learning model with the values of social-spiritual attitudes, learning activities become more directed and systematic and can focus students' attention in learning. 
8.The quantum learning model with the values of social-spiritual attitudes provides opportunities for students to learn according to what students want through the exploration of experiences held by students and utilizing the experience as initial information to carry out further learning.

9.The quantum learning model that has the value of social-spiritual attitudes provides opportunities for students to learn according to their abilities, how use an interactive process to assess what they know, identify what they want to know, evaluate what students can do.

10. The quantum learning model with the value of social-spiritual attitudes provides opportunities for students to be actively involved in the learning process, interacting both with material, friends and lecturers.

11. Through the implementation of the quantum learning model that has the value of socialspiritual attitudes, it gives a sense of comfort to students when students who dare not ask directly, so students can write their problems on the reflection sheet. Some of the obstacles or shortcomings encountered during the learning process in this study by implementing the quantum learning model contain the values of social-spiritual attitudes, namely as follows.

1) Lecturers cannot provide guidance evenly to students, given the limited time available. 2) Some material is rather difficult to find the context. Based on this, the lecturer is required to be more creative in finding the context of each material studied in daily life. 3) Some students are not accustomed to exploring every moral meaning / message contained in the material.

4) Some students are not used to asking questions, giving opinions, and discussing with classmates

\section{Conclusion}

Based on the results of the research and discussion conducted, it can be concluded as follows. (1) Application of quantum learning models containing social-spiritual values through lesson study can improve students' social-spiritual attitudes. This can be seen an increase from cycle I to cycle II by 13.28\%. (2) Application of quantum learning models containing social-spiritual values through lesson study can improve learning outcomes of students' basic science II concepts. This can be seen increasing from cycle I to cycle II at $12.25 \%$. Based on the findings of this study, it is recommended that teachers / lecturers use the quantum learning model with the value of social-spiritual attitudes as an alternative to innovative learning models in order to improve the social-spiritual attitudes and learning outcomes of students. Further researchers are advised to examine in a relatively longer time to see the effectiveness of the quantum learning model with the value of social-spiritual attitudes in improving the social-spiritual attitudes and learning outcomes of students.

\section{References}

A’la, M. (2010).Quantum Teaching. Yogyakarta: Diva Press.

Astawan, I G. (2010). Pengaruh Model dan Gaya BelajarTerhadapPemahamanKonsepdanKemampuanPemecahanMasalahSainspadaSiswaKelas IV SD. TesisTidakditerbitkan.Singaraja: Program PascasarjanaUniversitasPendidikanGanesha.

Astawan, I G. (2013). Pengaruh Model Pembelajaran dan gaya Belajar Terhadap Pemahaman Konsep dan kemampuan Pemecahan Masalah Siswa Kelas IV SD. Jurnal Ilmiah Pendidikan dan Pembelajaran. Vol. 9, No. 3, Juni 2013.

Degeng, I N.S. (2001).LandasandanWawasanKependidikan. Malang:

LembagaPengembangandanPendidikan (LP3) UniversitasNegeri Malang.

De Porter, B., Reardon, M., danNourie, S.S. (2003).Quantum Teaching: Mempraktekan Quantum Learning di Ruang-RuangKelas. Terjemahan: AryNilandari. Bandung: Kaifa.

DePorter, B \&Hernacki, M. (2003).Quantum learning: MembiasakanBelajarNyamandanMenyenangkan. Bandung: Kaifa.

Herdian.(2009). ModelPembelajaranKuantum, (Online), (http://herdy07.wordpress.com/2009/04/29/model-pembelajaran-quantum/diakses 24 Mei 2011). 
Konsorsium Indonesia.(2010). Pendidikan IPA.tersediapadahttp://pendidikanIPA.blogspot.com/2008 0901 archive.html, diaksestanggal 1 Septem-ber 2010.

Rati, N. W. \&Astawan, I G. (2011).Pengaruh Model PembelajaranKuantumTerhadapPemahamanKonsepdanKemampuanPemecahanMasalahKonsep IPA Mahasiswa Semester II JurusanPendidikan Guru SekolahDasar.LaporanPenelitian (tidakditerbitkan). Jurusan PGSD, FIP Undiksha.

Sekeretariat Jenderal MPRRI. (2012). Ketetapam MPR RI No. VII/MPR/2001 tentangVisi Indonesia masadepan.

UNDP. (2009). Statistics of The Human Development Report. http://hdr.undp-org/en/statistics/, DiaksesJumat, 23 Januari 2009.

Widiastini, Ni W. E. (2012). Pengaruh Model Pembelajaran Kooperatif Tipe STAD Terhadap Hasil Belajar IPS dan Keterampilan Sosial Siswa Kelas V SD Laboratorium Undiksha. Jurnal Ilmiah Pendidikan dan Pembelajaran. Vol. 9, No. 1, Oktober 2012.

Wiratma, I G. L. (2010).PolitikPendidikandalamPengembanganKesadaranKritisdanJatiDiri.Jurnal IKA. Vol. 8.No. 2.Hal.107-122. 